\title{
POLUTION OF BASIC NATURAL RESOURCES WITH HAZARDOUS MATTERS
}

\section{Ljubo Pejanović ${ }^{1}$}

\section{Summary}

The paper analyzes conceptual guidelines and a multidimensional approach to the thematic of agriculture as a land property with rich and available natural resources, which are characterized by their specifics. Specifics of natural resources are characterized by renewable and non-renewable contents without which life is impossible, and these basic contents are land, air and water. In addition, agrarians and agriculture have natural riches in their possession, out of which food for living creatures on the planet is produced.

Natural resources are the contents of agrarians and with every pollution, and thus destruction of natural resources, it damages and destroys sustainability of both natural resources and the sustainability of agriculture with its content of living creatures and plants on which life and survival on this planet depend on.

Any pollution, especially from hazardous substances and excessive treatment from the air and ground, causes damage, destruction and loss of life which is contained by living creatures and plant life, a prerequisite for sustainable development and the survival on Earth.

The problem and aim of this paper is to point out and prove a phenomenon of the modern world, which poses a threat to the survival of natural resources, and thus life to living things and plant life on Earth. However, the aforementioned phenomenon is not a much known one, it's only known to a shortlist of scientists and theoreticians, while the general public is not aware of the mentioned and doesn't even assume the consequences of the threat.

Key words: pollution, resources, agriculture, dangerous, matter.

JEL: $Q 54$

1 Ljubo Pejanović Ph.D., Associate professor, University Union in Belgrade, Faculty for legal and business studies dr Lazar Vrkatić, Bulevar oslobođenja no. 76, Novi Sad, Phone: +38163438649, E-mail: pejanovicljubo@gmail.com.

EP 2015 (62) 4 (1095-1107) 


\section{Introductory remarks}

First of all we point to the problem of pollution, and with that the destruction of a number of natural resources, which among other things is the basis for survival of agricultural, i.e. sown plants and food products (fruits, vegetables, grains and so on). Life on Earth depends from planted products and other resources. Secondly, work warns on artificial contamination of certain natural resources, among which are: water, soil and air which, if they were polluted, there wouldn't be sustainable development of agriculture, or the environment (Kristoforović-Ilić, Ilić, 2006).

Therefore, any pollution of the aforementioned renewable and non-renewable natural resources, through artificial spraying from aircrafts, represents a major problem for the safety and survival of life on Earth.

So, the basis of our assumptions on the problem is constituted by the application of impermissible, experimental and dangerous substances such as: explosive, radioactive, toxic and polluting substances. These substances drastically pollute agriculture and the environment. Resorting to hazardous materials by contractors is aimed at, research for scientific purposes, as well as threating threats, through which human lives are endangered, as well as the lives of other living creatures and plant life.

Dangerous materials and their contents such as poisons, radiation and explosive materials are; nuclear, biological and chemical weapons, as well as treating the planet with chemical and biological agents. Through the use of above mentioned substances certain metals, viruses and bacteria are discarded. The presence of these dangerous matters, causes great diseases and epidemics in humans, then diseases and pandemics of other living beings.

The stated problem aims to prove and give proof of the threats to agrarians, through the presence of hazardous substances, as well as consequence caused by them.

In researching this problem, the methods of analysis and synthesis will be applied, through which necessary answers and adequate conclusions will be obtained about the set problem.

\section{Theoretical bases for researching dangerous threats and occurrences}

The area of research and theoretical proofs of threatening security phenomena in agrarians and ecology, virtually did not even attempt to officially investigate this sphere, or was marginally mentioned in the international community, including the Republic of Serbia. Very little attention was paid to this phenomenon by the individuals of the Military Medical Academy in Serbia, in addition to the problem of the modern world. On the other hand threatening security occurrences, were most often mentioned on the basis of experiences of individuals or small groups of people as researchers. Therefore, our interest and commitment to this issue arose on how to bridge this gap and link between interpretation i.e. observation and research in this sphere and ecological occurrences in practice today. Thus, the contribution to the theory and science through this paper is to point out and prove the consequence it had with agrarians, ecology and 
the lives of living beings, from the aforementioned threats.

The theoretical consideration of the aforementioned threats in ecological-security occurrence as a political, legal, economic and sociological definition of these phenomena. Through the occurrence mentioned above, agrarians are polluted, and thus represents a threat to overall security in a certain area.

First of all, in theory, threatening security occurrences in their existing state are a part of social reality i.e. an integral element of the social whole of the new era. In order to perform the necessary research of this phenomenon, it is necessary to apply the necessary and inevitable research methods.

The process of investigating and explaining actual events will be applied by using the synthesis method, and through the merger of given activities in complex problems which are a threat to the economy and ecology. While using the analysis method, a process of research and explanations of reality and its parsing will be applied, starting from complex into simpler parts of reasoning a given problem.

\section{Threatening ecological occurrences}

The modern world that surrounds us is made of numerous natural and social phenomena that are intertwined, overlap and complement one another, and thus influence each other. Observing artificial natural phenomena which occur independently, and not often independently from the awareness from people who plan, organize and impose certain threats. These threats were directed at the international community, as well as the specific region in which the Republic of Serbia is found. In relation to our understanding of human activities, the eventuality of an influence on climate change in natural and artificial sense is a possibility. In this case man influences and changes the nature, and therefore society, with his activities and operations, such as the disposal of uranium, plutonium and chemical-biological agents. Thus, the social phenomena in this regard, occur as a result of related actions of certain societies and their institutions (Mihajlović, 2014). Accordingly, the occasional and often everyday occurrences, produce and cause serious threats, and thus the security changes in a negative process. The threats to human society in recent times are made from the changes in the security situation in an unsafe one, in the direction of breaching health safety and life in living beings, as well as the destruction of plant life.

Therefore, in the very act of using nuclear, chemical and biological weapons and other dangerous devices, a series of dangerous and complex activities are imposed, which in their content consist of specific processes that cause threat of pollution, poisoning, injury, loss of life and thus the achievement of the desired goals of providers. In this sense, the essential characteristic of threating security threats is that they are created by certain countries and their institutions, not by individuals or groups of people. Resorting to the use of dangerous weapons for mass assassination, destruction and poisoning, doesn't only represents a threat to health security in people, but also psychological factors that cause fear, panic, health disorders and related troubles of these emerging threats. 


\section{Causes of threat occurrences}

In this sense, the causes of threatening ecological-security phenomena vary, among which are: political, economic, doctrine, strategical and tactical. The causes of the manifestation of the above mentioned issues can exist in a particular society or by influence of a different country or groups of countries on a particular society or country. Looking at the NATO aggression against the FRY and the RS, threats which were manifested by a group of countries on a single society i.e. country. While the application of Chemtrails and HAARP system is the influence of a part of the international community on more societies or places on Earth.

\section{Chemtrails and HAARP systems}

1. Chemtrails is a system known for chemical white traces in the air, caused by discharging from jets with white trace i.e. chemical that disperse and spread through the air causing new occurrences in the form of a white cloud. By creating a network of poisons of chemicals around the Planet, justifying and explaining all of that, by saying that it prevents the sun from getting too hot. Therefore, the Germans have admitted that the planet is overflown by unmarked planes that carry and disperse sulfur which is allegedly being burned in the plane and under high pressure being created in sulfur dioxide. Next to sulfur dioxide, it releases aluminum, various viruses and other hard metals are released in the atmosphere, whose assignment is to fry the natural resources, destroy the earth and make it suitable for a genetically modified organism (GMO).

2. HAARP as a system connects to the Chemtrails system, whereby they influence climate changes and natural disasters. In this regard, some scientists wonder and indicate that the third world war, in a sense began over ecology (http://www.novosti. rs/vesti/naslovna/reportaze/aktuelno.293 html:456965-Kemtrejlsi-i-HAARP-tajnooruzje-SAD). Many prominent world theoreticians and scientists have warned for years about this phenomenon. Among them is $\mathrm{PhD}$ Nikolas Begič, who actively participates in the campaign against experiments which are made in the HAARP program (HighFrequency Active Aural Research Program in Alaska). Experiments are made by very powerful technology for the production of high frequency electromagnetic waves by bombarding particles in ionosphere and thereby getting heat up. Electromagnetic waves then bounce back at extremely low frequencies penetrating everything on earth, i.e. alive and dead. In humans, this method can cause brain damage. The modification of climate aims to cause hostile states long droughts and floods, which was written in a book by Zbigniew Brzezinski (Živković, 2005).

\section{The concept and definition of polluting the environment with dangerous matters}

Before we approach to considering and defining the problem of polluting the environment by using dangerous matters, it is necessary to explain what is known about this, what is written, what is new and what is suggested? Therefore, having this in mind, we are 
mentioning the following data and proofs:

- When it is talked about NATO aggression on Yugoslavia and Republic of Srpska, the entire international community knows very well that the act of aggression and the goal of that act, is with made up reasons and executed scenario. However a small number of states or nations know about the aftermath of this act of violence, while most don't even know the real consequences. After executing the aggression from air and using devastating bombs with the amount of about $34,000 \mathrm{~kg}$ of dangerous matters, larger amounts of depleted uranium and plutonium was released (Rajković et. al., 2001). Having this in mind, due to the presence of depleted uranium and plutonium, a large number of citizens has gotten ill from carcinoma in Serbia, as well as Republic of Srpska, but also other surrounding countries. However, Italian soldiers have also had health consequences from radiation on Kosovo and Metohija (Chomsky, 2001). Therefore, this problem is not a commonly known or written about. The proposition for the solution of this non-humane phenomenon is the only possible on, for the international community to accept and confess its mistake and approach to cleaning the polluted environment from depleted uranium and plutonium which are present in larger amounts on Kosovo and Metohija, South Serbia, (RS) Hadžić, Han Pijesak and other areas.

- As for environment pollution with chemicals through „Chemtrails system“, this problem is only known to the experts who are dealing with this type of research, while the rest of the population doesn't know or understand what it is about. The released chemicals contain several types of metals and chemicals, which have an effect on living organisms, due to what people and other living beings get ill. Recommendations for the solution of this problem are only possible by rejecting this way of influencing climate change and leave the same to nature and not irritate nature for it to react to every human activity, even a one of this kind.

Therefore, the conceptual definition of hazardous and explosive weapons with the contents of depleted uranium, chemical, biological and radiological means, represents a devastating weapon for mass killing and destruction of natural and social values and space. According to this, devastating chemical, biological, radiological and nuclear weapons are the means of destroying military forces, killing of citizens and destruction of property on foreign territories. Republic of Serbia and its area are totally polluted with dangerous matters which represent a huge consequence to the safety of life and the environment. There by, pollution of the environment implies an illegal and unacceptable postponement of devastating, explosive and radioactive weapons, which caused pollution of the environment, due to what great consequences for the safety of people, property and other social values have occurred.

Analysis of the bombed spaces and their pollution in Yugoslavia, Bosnia and Herzegovina and Republic of Srpska

„However it should start from the first truth represented by Košik (2010) in the time of bombing: weapons and capabilities of command headquarters were being tested on live 
goals in the war against Serbs, but also the psyche of people was examined. This is why it can be freely said that his analysis on the effects of the bombing which has an effect even today, acts on the health and psych of the inhabitants of Montenegro (Drecun, 2013). That tragic year of 1999 has had 78 days of bombarding which caused 2000 civilian and 1002 soldier deaths. 36,219 flights of military airplanes were executed. NATO planes were flying at the height of about $10-15 \mathrm{~km}$ where the ozone layer is. The depleted uranium was used at 113 locations on the area of today's Yugoslavia" (http// www.novinar.de/2007/11/09/posledice-bonbardovanja-srbije-1999-godine.htm/).

NATO armed forces have executed a bombing on Yugoslavia, Republic of Srpska$\mathrm{BiH}$, and with this Republic of Serbia from air (http://mondo.rs/a104083/Info/Ex-Yu/ BiH-Posledice-uranijuma-zabranjena-tema.html). In the aggression on the Republic of Serbia, military, police objects, industrial objects of NIS, in Novi Sad, Pančevo, Belgrade and other areas were bombed. Other than those, Hospital Dragiša Mišović in Belgrade, Novi Pazar, passenger train in Varvarin, Tower on Avala and multiple repeaters and civilian objects in Aleksinac, Belgrade, Pančevo, Niš, Novi Sad, Leskovac, Sombor, Subotica, Herceg Novi, Bačka Palanka, Kruševac, Trstenik, Vladičin Han and other places. A military intervention was executed on armed forces and some objects in the Republic of Srpska-BiH in Hadžići and Han Pijesak. Airports in Belgrade, Priština, Užice, Kraljevo and multiple objects around airports, refineries, police station barracks and like were destroyed (Smiljanić, 2009). Expulsion of devastating and explosive projectiles from airplanes, which contain chemical, biological and nuclear matters, objects of special social interest were destroyed, as well as civilian objects, which caused irreparable material damage, loss of human life, a large number of people got ill from carcinoma and the environment was polluted.

General information on the consequences after the bombing of Yugoslavia and (Republic of Srpska)

Ecological and health consequences from NATO bombing in 1999 has drastically increased, with an accent on depleted uranium. Hence, "the number of diseased by cancer in 1999 was 9,899, while in 2000 this number jumped to 22,123 , and in 2010 to 26,152, to go to 33,000 in 2011, while the number of dead from cancer was between 55 and $60 \%$ each year".

With this in mind, the Swedish health organization (WHO) and international community for atomic energy (IAEA), as well as the Swedish Radiation Protection Institute and UNEP and based on gathered data, measurement of radioactivity and their threat on humans was executed. Based on these reports, dangerous bombed zones in those areas in which depleted uranium was used were determined. Therefore, a working group for Balkan was established and it confirmed the existence of four environmental hot spots in four areas, which are: in Pančevo, Kragujevac, Novi Sad and Bor, where major threats and irreparable consequences were established on health and life safety of people and other living things. Based on this, they predicted security protection by cleaning these environments, in order to avoid major consequences on health safety in 
people. With this research the teams have established a large amount of radiation in the mentioned zones, as well as in rivers Dunav and Timok (UNEP, UNCHS, 1999). The presence of large amounts of radioactive matters and resources. The presence of large amounts of radioactive materials and resources has created the conditions for illnesses in humans and animals, which is why there has been and there will be diseases caused by carcinoma in large number of people, and with this loss of life.

\section{The consequences are removed slowly and in an inadequate way}

At the end of 2003 (11.12.) 139 undamaged capacitors filled with cancerous transformer oil-pyralene have went through France, to the French plant „کŠše“, the biggest in Europe for destruction of dangerous matters, where they will be melted. The total amount of hazardous waste, placed in special containers is about 5.5 tons. In the municipality of Bujanovac, at the location of Bratoselce, during 2003, 350 bullets containing depleted uranium were extracted. During 2004, the cleaning of Pljačkovice next to Vranje was finished, where at an extremely inaccessible terrain 48 bullets with depleted uranium were found, there is no data on the numbers left. Department for Environmental Protection of the Ministry of Science and Environmental Protection has signed a contract on realization of the project of remediation of depleted uranium contaminated area on the location of Borovac, on the territory of municipality of Bujanovac on the 19.07.2005 with the institute of nuclear science. Announcements from the line ministry say that the recovery of the Reljan location in the municipality of Preševo should be done in the following year, with which the recovery of all locations contaminated with depleted uranium on the territory of Serbia outside Kosovo would be finished (Simeunović, 2000). "However, a question is raised, why the international community, western European and economically developed countries don't make the effort to reduce the consequences to a minimum, since they allowed for this inhumane criminal act of violence." These consequences will cause harm, not only to the citizens of $\mathrm{BiH}$ and Republic of Serbia, but also citizens of neighboring countries, as well as citizens which have and will pay a visit to this region. Waste as an agent doesn't recognize citizens by their nationality or state lines. Why don't they do it for their citizens, if not for the citizens of the Republic of Serbia?

\section{Contamination by ejected uranium and time after}

„The international commission intentionally reduces damages which are created by bombing from uranium waste and other dangerous matters. The data the UN Program for protection of the environment, a professional organization in the UN system, at the request of former Federal Government has published the examination on the state of the environment in three key missions, says that something is being done on the international plan (Đinović, 2013). Each mission was composed of experts from multiple countries and analyzed a dozen industrial locations: Pančevo, Novi Sad, Kragujevac, Bor, Niš and a few thermal power plants. Then Dunav and several localities from the point of endangering the environment such as Kopaonik, Fruška Gora and Zlatibor. At the same time, the same job, in the same amount was being done 
by our experts, and it is interesting to say that the published results from the UN and our experts are different in certain findings, but those differences are within the limits of acceptability..." (Košik 2010). With this in mind, the authors raise the question, what happens seven years after the NATO aggression on these two states, and beyond? What after? The data will be shown seven years and much after that by results of the illnesses of the citizens on entire Balkan area, and especially in towns surrounding Pančevo, Novi Sad, Kragujevac, Niš, Bor, Fruška Gora, Zlatibor, Kopaonik, Košar, river Dunav and the area of Kosovo and Metohija (Akame, 2010). Outside these areas, the results from the citizens of Albania, Bulgaria, Italia and other countries will show! Therefore it would be useful for the government to seriously accept the real state and seriously address this dramatically large problem because of the safety of citizens in Republic of Serbia, and wider.

\section{Disposal of chemical and biological agents through Chemtrails system}

A larger number of countries in the International community, professional crews and teams are carrying out measurements and take samples from chemical agents' residue which were ejected from planes which were doing airspace "testing", on a large part of planet earth. According to the analysis of certain private laboratories on these matters, there were certain biological and pathogenic agents from microorganisms and certain metals, such as: salt, barium and micron dimension aluminum particles and like. In addition certain specific agents were found, such as:

- Pseudomonas Aeruginosa, which contains a bacteria that attacks the respiratory system in living beings,

- Pseudomonas fluorescens, which contains a bacteria which causes infection of blood and respiratory system,

- Serratia marcescens, which causes inflammation of the brain, heart muscle and other things,

- All kinds of radioactive and nerve poisons which appear as cobwebs and flowers of poplars which cause skin disease in the form of pimples, eczema, ulcers, all the way to burns.

In addition to these, about eight heavy metals that cause various diseases, especially skin cancer is contained (Jovanović Batut, 2011). Because of the scale of this work there is no place to display all content and sites. "For more than about 8 years, the so-called. "Secret government" performs intense "dusting" of this planet population from the air. It's about airplanes for these purposes, specially modified aircrafts that eject i.e. disperse certain biological agents from high-altitude, whose exact chemical composition is currently unknown for the Republic of Serbia, while in other countries, certain analysis as well as the purpose due to which such operation is being done was performed. No matter that many appeals were lodged by the citizens, especially in the USA, the existence of such an operation is officially denied, and all of those who are publicly speaking about this problem are automatically classified in the category of conspiracy theorists. "Uranium, plutonium, contents from cluster bombs, chemtrails 
testing, HAARP radiation have greatly polluted the earth, air and water and by this make the agriculture useless and dangerous for health and safety in general.

\section{Characteristics of uranium}

"Uranium which remains after the removal of enriched fraction contains $99.8 \% \mathrm{U} ; 0.2 \%$ up to $0.3 \%$ in and around $0.001 \%$ "Ui" signifies depleted uranium. Nuclear regulatory commission US defines depleted uranium, as the one in which the percentage of " $U$ " is lower than $0.711 \%$ (NRC 2000). Typical composition which is used by the Ministry of Defense of the US is $U=0.0006 \%, U=0.2 \%, U=0.0003 \%$ and $U=99.8 \% \ldots$ Uranium from depleted reactive fuel is sometimes processed in plants for uranium enrichment... The United nations program for environmental protection (UNEP, 1999) has found on Kosovo and Metohija 12 Bq/kg U and 12700 kBq/kg for U.” (Đurović, et. al., 2011)

"Natural radiation is the emission of radioactive substances which are not the product of men. Uranium, radon and other rare elements can be found among these substances. They are very dangerous for the health of man when they are dug up or milled, from where they derive in food, air and water.

Artificial radiation, includes the emission of radioactive substances which can't be found in nature or are the result of nuclear fission processes."

By studying the characteristics of natural and artificial emissions of radioactive matters, it can be concluded that a sudden increase of illness in citizens from carcinoma, the cause can be uranium, plutonium and other forms of radiation which can be found close to people. Illness is caused by the presence of uranium and other dangerous matters in the air, earth and water. Through these three natural energy sources that are the basic natural resources without which life is impossible, and with which living beings are in a direct connection through the usage of air, water and natural products from the land.

The application of HAARP program in polluting the agriculture and (ecology) of the environment

The application of the (HAARP) High Frequency Active Auroral Research Program, i.e. the system which uses the mobile frequency antenna from GWEN towers (Ground Wave Emergency network), is a big problem and represents a danger from illnesses for people with its radiation. In addition to the dangers of getting a disease through the system, with the presence of crystals which are obtained through administration of the system, causes damage to the human mind through contamination of the brain, and implementation of genetic mutations in humans. HAARP project system works through simulation and control of ionosphere processes that can alter and improve performance of communication and related systems. Through HAARP, energy pulses of $3.6 \mathrm{MW}$ can be focused over frequency range of between 2.8 to $10 \mathrm{MHz}$ in ionosphere.

Therefore, the combination of HAARP and Chemtrails system, managing and conducting climate changes on narrower and wider areas i.e. space is being done. Artificial change of climate changes, at the same time artificially works on the psyche 
and health of men. In addition to ejection of chemical contents from aircrafts which are dangerous to health on their own, and at the same tome conducting through the HAARP system which is also dangerous to man, there is an additional endangerment of human safety. From the mentioned artificial actions, illnesses in people occur, and with this threats to safety of life.

\section{Pollution of agriculture and the environment with consequences on the Republic of} Serbia

Due to the aggression on the area of Republic of Serbia there is still a large and unsolvable problem of adequate equipment for finding and deactivating cluster bombs, mines and other parts of devastating tomahawks due to lack of will from certain governments, lack of money and international foundations, lack of professional-qualified staff for removal of dangerous matters. When it comes to the international factor and its assistance in this matter, one of the few countries is Norway, whose government has provided 3.5 million euros for the search of sector-port Prahovo for detection and removal of residual air bombs i.e. missiles. Norway has provided 3.5 million euros in the next three years for clearance of cluster munition from the territory of Bujanovac, Presevo and Kursumlija. Help was promised from Russia that is, its agency "Emerkom" in demining in two locations, this is partly carried out in Paraćin, and cost was at about two million dollars. When it comes to this location, Russia conducted demining at three micro locations in Paraćin in 2009 and 2010.

In this action 1,253 unexploded different pieces of ordnance were found and destroyed. This location was further endangered by an outbreak of fire in an ammunition warehouse in Paraćin during 2006 and this case has nothing to do with NATO bombs, but this represents a major threat to the safety for humans in the area (Mihailović, 2011). During 2006, at the location "Industrial Zones" in Niš deactivation of cluster bombs has been carried out and then a miner suffered serious injuries by his negligence, with permanent blindness. This activity was conducted by one chosen firm in the Republic of Srpska. According to this a large number of thrown cluster and air bombs left unexploded, and self-flying bombs i.e. "Tomahawk" which have exploded and polluted the area, both in buildings, plains, and rivers. All of the above leads to a large and a hard to solve problem, both in deactivation, and cleaning the consequences of radiation from dangerous chemical, biological, radiological and nuclear materials.

\section{Instead of a conclusion}

NATO aggression by air bombing in 1999, is an internationally illegal act of violence against a small and underdeveloped country which was supported by NATO Alliance member states (Belančić, 2004). Aggression with the use of the most advanced military aircrafts and the use of most dangerous weapons of mass murder and destruction, caused the death of about 3000 people at the given time, and how many will lose their health and life from the consequences of nuclear, chemical, biological and radiation weapons, cannot even be assumed, especially if we have in mind that 250,000 citizens of Serbia 
are treated from carcinoma. The aggression with the most dangerous weapons of mass destruction, disastrous polluted environment, primarily in the Republic of Serbia, then in Montenegro and Bosnia and Herzegovina, has not much spared any country in the region and beyond. Ejected uranium on the territory of the Republic of Serbia and the Republic of Srpska, will pose a treat for centuries (4500 years according to the statement of the expert team on VMA) to the lives of living beings and their survival in this region. According to existing current statistical data, we can see how people suffer from a serious disease called "cancer", and how many more will become ill in the years to come, we can't assume. Secondly, which increases the threat in this area, is the activity of scientific institutions from economically developed countries is the activity with re-manufactured civil aircraft which are used to treat earth with chemistry. All that is intended to influence climate change. The influence of artificial climate change causes the destruction of agriculture, pollution of agriculture, environment pollution, diseases and ailments in a large number of citizens in the Republic of Serbia. This illegal act caused disasters on large scale, thus destroying enormous material values and causes loss of human life. Whereby, large amounts of chemical agents whose presence endangers health, and thus lives of humans are ejected. Then, pollution of air, water and land, and therefore food products. As far as the HAARP system through which climate change is controlled, and natural disasters caused in conjunction with chemtrails system poses an additional threat to the radiation from repeaters through which direct rays and energy are directed. On the asked question, which is a more cost-effective economic justification for aggression, chemtrails, HAARP or other resources, an answer can be found here, that it is economically justified only to executors and owners of the above mentioned assets. The international community and economically developed countries would need to allocate considerable financial resources, equipment and experts, to cleanse the polluted area. Consequently, they alone bear the greatest responsibility for the catastrophe which is in this place. It would be a major contribution to exert pressure for an end to treating the planet through chemtrails and HAARP system.

\section{Literature}

1. Akame, F. (2010): Amerika poslala smrt na Kosovu, Energetika.

2. Belančić, M. (2004): Nasilje, Beograd, (available at: http://miloradbelancic.com/ book/nasilje-2/ ).

3. BiH: Posledice uranijuma zabranjena tema?: (available at: http://mondo.rs/ a104083/Info/Ex-Yu/BiH-Posledice-uranijuma-zabranjena-tema.html).

4. Chomsky, N. (2001): A Review of NATO's War over Kosovo, Z Magazine.

5. Drecun, M. (2013): Rat za Kosovo, Miba Books, Beograd, Srbija, ISBN: 9788689595062.

6. Đinović, V. (2013): Uticaj postpupka revalorizacije po finansijski položaj preduzeća, Oditor, Belgrade, Serbia, No. 4, pp. 14-19.

7. Đurović, B., Spasić-Jokić, V., Petković, S., Fortuna, D., Selaković-Mićunović, V., EP 2015 (62) 4 (1095-1107) 
Atlagić, N. (2011): Osiromašeni uranijum-metode detekcije, saniranje neposrednih efekata i prevencija kasnih posledica, Beograd, Autorsko izdanje.

8. Jovanović Batut, M. (2011): Cancer incidents and mortality in central Serbia, Cancer registry of central Serbia, Belgrade, Serbia, report no. 13

9. Košik, K. (2010): Posledice bombardovanja Srbije 1999. godine,_(available at: http//www.novinar.de/2007/11/09/posledice-bombardovanja-srbije-1999-godine. $\mathrm{htm} /)$.

10. Kristoforović-Ilić, M., Ilić M. (2006): Aerozagađenje i zdravlje ljudi, Institut za zaštitu zdravlja, Institut za plućne bolesti, Vol. 134, No. 2, pp. 145-149.

11. Mihailović, P. (2011): Nato bombe još prete, dnevni list Politika, (available at: http:/www.politika.rs/rubrike/Drustvo/NATO-bombe-jos-prete.lt.html)

12. Mihajlović, M. (2014): Menadžment znanja kao factor povećanja efikasnosti organizacije, Oditor, Belgrade, Serbia, No. 9, pp. 33-36.

13. Rajković, M. B., Pantelić, G., Petrović I. (2001): Determination of uranium contents in the soils, Journal of Agricultural Sciences, Vol. 46, No 2, pp. 163-174.

14. Simeunović, D. M. (2000): Bitka za Kosovo i Metohiju - istorija, aktuelno stanje $i$ perspective, Vojno delo, Vol. 52 No. 1, pp. 16-39.

15. UNEP, UNCHS, (1999): The Kosovo conflict, consequences for the environment, United Nations Environment Programme and the United Nations Centre for Human Settlements, ISBN 92-807-1801-1.

16. Živković, I. (2005): Zemlja kao oružje, (avaiable at: http/www.ivonazivkovic.net/ haarp.htm).

17. Smiljanić, S. (2009): NATO agresija - ratno vazduhoplovstvo i PVO i odbrana otadžbine, II izdanje, Beograd.

18. http://www.novosti.rs/vesti/naslovna/reportaze/aktuelno.293.html:456965Kemtrejlsi-i-HAARP-tajno-oruzje-SAD. 


\title{
ZAGAĐENJE OSNOVNIH PRIRODNIH RESURSA OPASNIM MATERIJAMA
}

\author{
Ljubo Pejanović
}

\begin{abstract}
Rezime
U radu su analizirane pojmovne odrednice i višedimenzionalni pristup tematici agrara, kao zemljišnog poseda s raspoloživim i bogatim prirodnim resursima koji se odlikuju svojim specifičnostima. Specifičnosti prirodnih resursa odlikuju se obnovljivim $i$ neobnovljivim sadržajima bez kojih je život nemoguć, a te osnovne sadržaje sačinjavaju zemlja, vazduh i voda. Poljoprivreda raspolaže sa prirodnim bogastvom na kojem se proizvodi hrana za sva živa bića na zemlji planeti.

Svako zagađenje a time i uništavanje prirodnih resursa oštećuje se i uništava održivost, kako prirodnih resursa, tako i održivost poljoprivredne proizvodnje koja obezbeđuje hranu za ljude i životinje, odnosno opstanak na planeti Zemlji.

Svako zagađenje, a naročito opasnim materijama i prekomerno tretiranje iz vazduha $i$ sa zemlje, doprinosi oštećenju, uništenju i nestanku života koji je sadržan od živih bića i biljnog sveta, koji je uslov za održivi razvoj i opstanak života.

Cilj ovog rada je ukazivanje i dokazivanje na fenomen savremenog sveta, koji predstavlja pretnju uništenju prirodnih resursa, a time života na Zemlji, odnosno uništavanje flore i faune. Nažalost, za navedeni fenomen se mnogo ne zna, samo je poznat užem broju naučnika i teroretičara, dok šira javnost o navedenom problemu i pretnji opstanka nije upoznata i ne pretpostavlja koje su posledice navedene pretnje.
\end{abstract}

Ključne reči: zagađenje, resursi, poljoprivreda, opasne, materije.

2 Vanredni profesor, dr Pejanović Ljubo, Univerzitet Union u Beogradu, Fakultet za pravne i poslovne studije dr Lazar Vrkatić, Bulevar oslobođenja br. 76, Novi Sad, Telefon: +381 63 438 649, E-mail: pejanovicljubo@gmail.com

EP 2015 (62) 4 (1095-1107) 